\title{
Exploring Malaysian Household Consumers Acceptance towards Eco-friendly Laundry Detergent Powders
}

\author{
Parthiban Siwayanan ${ }^{1}$, Nooh Abu Bakar ${ }^{2}$, Ramlan Aziz ${ }^{1} \&$ Shreeshivadasan Chelliapan ${ }^{3}$ \\ ${ }^{1}$ Institute of Bioproduct Development (IBD), Universiti Teknologi Malaysia, Johor Bahru, Malaysia \\ ${ }^{2}$ Malaysia-Japan International Institute of Technology (MJIT), Universiti Teknologi Malaysia, Kuala Lumpur, \\ Malaysia \\ ${ }^{3}$ Razak School of Engineering and Advanced Technology, Universiti Teknologi Malaysia, Universiti Teknologi \\ Malaysia, Kuala Lumpur, Malaysia \\ Correspondence: Parthiban Siwayanan, Institute of Bioproduct Development (IBD), Universiti Teknologi \\ Malaysia, 81310 UTM, Johor Bahru, Johor, Malaysia. Tel: 60-13-612-8425. E-mail: sparthi@yahoo.com
}

Received: September 9, 2014 Accepted: November 20, 2014 Online Published: April 2, 2015

doi:10.5539/ass.v11n9p125

URL: http://dx.doi.org/10.5539/ass.v11n9p125

\begin{abstract}
Due to the current environmental pressures and ever-rising prices of petrochemical feedstock, the detergent industry is gradually moving towards the development of green and eco-friendly products. However, besides the production cost, the challenge for today's detergent formulators still lies in increasing the quantity of green and eco-friendly surfactants in laundry detergent formulations without compromising their performance. Realizing this, research was undertaken to develop the Asian market preferred low-density laundry detergent powders by incorporating green palm oil based surfactant (known as MES) and also by eliminating the use of environmentally damaging phosphate-builders in the detergent formulation. Prior to commercialization of this newly developed eco-friendly low-density laundry detergent powder, a pilot survey was attempted over 112 respondents using mall-intercept approach in one of the popular shopping complex in Kuala Lumpur city with the aim to study consumers' preferences (format, brand, origin) and their purchasing behaviour (awareness/knowledge and perception) towards both commercial and MES based laundry detergent powders. The pilot survey results have indicated that the majority of respondents has high affinity towards green and environmental benefits offered by MES based laundry detergent powders. These positive results imply huge market potential for MES based laundry detergent powders and through effective marketing strategies and product awareness activities, this product is likely to attain success in the marketplace.
\end{abstract}

Keywords: green marketing, consumer preferences, purchasing behavior, consumer awareness/knowledge, consumer perception

\section{Introduction}

The one thing that unites all people is their interest in cleanliness. Cleanliness may have different definitions for different people but maintaining and restoring cleanliness is usually the top priorities of everyone, no matter where they live, whatever their social rank or whatever their age. Cleaning the clothes by means of washing has been among an individual's important task in a daily life. There are many varieties of cleaning products in the store nowadays and it comes in a variety of packages. These cleaning products are mostly laundry detergents in the format of powder, tablet, liquid or paste, suitable for hand or machine wash (Siwayanan, 2005).

Detergent industry is a highly competitive market and laundry detergent in the form of powders has the largest market share worldwide compared to other detergent formats. The major players in the business of laundry detergent powders are Procter \& Gamble (P \& G), Unilever, Henkel, Lion Corporation and Kao Corporation (Boerefijn, Dontula, \& Kohlus, 2007). Laundry detergent powders (LDP) formulated for washing clothes are typically contain surfactants, builders, bleaching agents, enzymes and fillers in various proportions. Among these ingredients, surfactants or surface active agents play a major role where its cleaning activity has been the driving force in detergent innovation for years (Lafferty, 2010). In 2008, the annual global production of surfactants was 13 million metric tonnes and the turnover reached US\$24.33 billion. It is expected that the global surfactant market would generate revenues of more than US\$41 billion in 2018 (Reznik et al., 2010). During the twentieth 
century, petrochemical based linear alkyl benzene sulfonate (LABS) has been the dominant surfactant in LDP formulations (Chemsystems, 2007) and Malaysia being one of the importers of this surfactant (Ahmad, Kang, \& Yusof, 2000).

Since the beginning of the new millennium, LABS has been under constant pressure due to escalating hike in crude oil prices (Foster, 2006; Scheibel, 2004). Moreover, green and eco-friendly became two big buzzwords in the marketing and production of detergents (Guala \& Merlo, 2013) and this development creates a great challenge to the detergent industry to find ways in increasing the green oleochemical based surfactants (De Guzman, 2010) and reducing environmentally harmful phosphate-based builders (Kohler, 2006) in the detergent formulations. In addition, this situation also has heightened public apprehension on petrochemical based LABS over its environmental impact towards the aquatic ecosystem (Huber, 1989; Okbah, Ibrahim, \& Gamal, 2013).

As part of the research efforts to address the challenges of the detergent industry, several detergent formulations were developed by increasing the amount of palm C16 carbon chain based methyl ester sulfonate (C16MES) and without the incorporation of phosphate-builders. C16MES, which drawn immense interest among the detergent manufacturers particularly in the Asian region (Giese, 2006), was mainly utilized in the formulation studies due to its commercial availability (Edser, 2010; Edser, 2011; Edser, 2013) and also because of its superior cleaning properties to LABS. C16MES has great potential as sole surfactant or co-surfactant in the production of LDP and was found to have the edge over LABS in the aspects of green, performance, production cost and sustainability (Adami, 2008).

The formulation studies have revealed that the synergistic effect between C16MES and linear alkyl benzene sulfonic acid (LABSA) at certain ratios can be used advantageously to produce non-phosphate based low-density LDP, which known as MES detergent powders (Siwayanan et al., 2014a; Siwayanan et al., 2014b). These detergent powders were found to demonstrate excellent cleaning performance, acceptable particle characteristics and lower production cost. They also possess excellent biodegradability and are unlikely to cause any serious impact to the aquatic environment. Since the experimental results were very encouraging, these detergent powders have enormous potential for commercialization. However, prior to commercialization process, it is necessary to gain market insights particularly about consumer preferences and consumer purchasing behaviour towards laundry detergent products at the targeted location where the new product is intended to be marketed.

In this paper, a pilot survey was carried out using mall-intercept approach with the aim to study consumers' preferences and also their purchasing behaviour towards commercial laundry detergents in general and particularly on MES detergent powders. Figure 1 shows the conceptual framework of the study, which emphasizes on the demographical characteristics and psychological factors that affect the purchasing decision of the consumers.

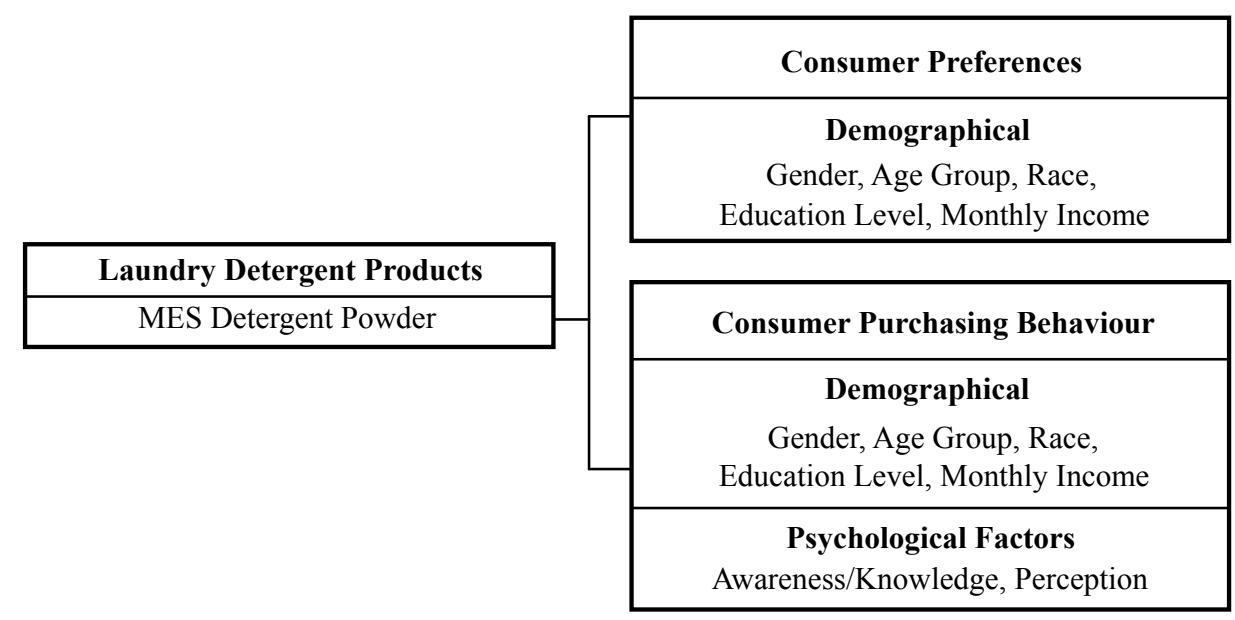

Figure 1. Conceptual framework of the pilot survey

\section{Literature Review}

Generally in any industries, the ability to commercialize new products quickly, effectively and efficiently that specifically addresses the needs of the consumers will determine the product success in the marketplace (Schilling, 2005). However, prior to commercializing or launching a new product, it is of vital importance for 
product manufacturers or marketers to understand the consumers' preferences and purchasing behaviour towards the product they intend to market. Besides knowing what the consumer wants and needs, some of the products also must be in compliance with the ever-changing regulatory requirements. This kind of information has a direct impact on the overall performance of the businesses and would be very useful in developing commercialization or marketing strategies.

Consumer preferences generally refer to the consumers' selection towards a particular product or services in accordance to their tastes and totally independent of income and prices. Preferences are created through an individual's religious principles, moral values, ideological characteristics, philanthropic impulses and sense of common destiny with family, clan, tribe, ethnic group or other forms of community (Shepsle \& Bonchek, 1997). Consumer preferences are not permanently fixed and often change over time depending on the purchasing trends of the consumers. Consumer purchasing behaviour, on the other hand, can be defined as decision making process and physical, mental and emotional activities involved while selecting, purchasing, using and disposing of either products or services (Samadi, 2003; Schiffman \& Kanuk, 1987). Three well-known major factors that have the influence on the consumer purchasing behaviour are personal (e.g., demographics), psychological (e.g., motives, awareness, knowledge, perception, personality, lifestyle, attitude) and social (e.g., opinion, culture, reference groups) (Bhagat, 2012).

Detergent industry is recognized as one of the industries that continuously involved in the development of new laundry detergent products. Since the beginning of the new millennia, the detergent industry has been moving toward the development of green and eco-friendly products due to change in environmental regulations and increase of petrochemical feedstock prices. Green and eco-friendly in the context of detergents may be defined as products that manufactured using natural or oleochemical based surfactants and will not harm the aquatic ecosystems. These features provide benefits not only to the environment but also the consumers. Besides the environmental regulations and petrochemical feedstock prices, there are two more significant factors that drive the development of laundry detergent products and these include the consumer preferences and purchasing behaviour.

\subsection{Consumer Preferences and Purchasing Behaviour}

The detergent industry has seen many changes on its consumers' preferences, particularly when it comes to detergent formats and brand images. Although laundry detergent products are available in a variety of formats but they differs from one region to the other depending on its consumer perception and expectation. For instance, in the 1980s, when P \& G introduced the Ariel brand concentrated detergent powder in India, they progressed without paying much attention on the washing habit of the Indian households where majority have the tendency to cling to detergent bars. Indians prefer the bar format over the powder because for them rubbing action is very essential to effectively clean the fabrics. P \& G, upon realizing the scenario, have eventually switched the format from powder into bar (India News Network Digest, 1994). After continuous attempts via promotions and advertisements especially from many multinational detergent companies, the preferences of the Indian households have slowly shifted towards the LDP. According to Euromonitor International (2013), 73.8\% of consumers in India are using LDP for both hand and machine wash. In 2013, the per capita consumption of detergents in India was about $2.7 \mathrm{~kg}$ per year (Choudhury \& Kakati, 2013).

Besides India, consumers in China also prefers LDP than any other detergent formats. Low cost per wash load and high volume over weight ratio (Kent, 2012; Yazaki, Tanaka, \& Nakamura, 1984) are the reasons for consumers to choose the powder format. In 2010, the per capita consumption of detergents in China was $3 \mathrm{~kg}$ per year and their detergent powder production accounted for about $14 \%$ of the world production (China Cleaning Industry Association, 2011). In Japan, on the contrary, concentrated detergent powders are well accepted by their consumers. The quality of the concentrated detergent powders plays a major role where consumers perceived these products as premium.

In North America and Western Europe, detergents in the form of liquid are very popular than powders (Euromonitor International, 2011). Tablets and sachets are relatively new formats in the market but they are highly preferred in the United Kingdom and other countries in the European Union. In Malaysia, detergent in the form of powder is still the preferred format for laundry detergent although there is an increasing market pressure from liquid detergents. In 2011, the per capita consumption of detergents in Malaysia was about $3.7 \mathrm{~kg}$ per year (Kulkarni, 2011). Based on the current recorded Malaysian population of 29.91 million people (Malaysian Department of Statistics, 2013), the calculated market size for laundry detergents is 110,000 metric tonnes. Generally, in Asia, the evolution in the detergent consumption habits and improvement in the standard of living due to modernization are the contributing factors that drive significant growth in the laundry detergent business. 
Brand image is another important factor that determines the consumers' decision towards purchasing LDP. It is a set of beliefs that consumers attach to the brand and seen as the means to deal with the competition (Domzal \& Unger, 1998). The competition among brands in the household market is getting tighter by day. Building a brand loyalty is a challenging task particularly when it comes to laundry detergents. A study on detergent brand preferences among Indian consumers has shown that the brand loyalty of the consumers changes over time (Mohankumar \& Shivaraj, 2010) and not lasting due to ever-changing tastes of the consumers. Meanwhile, Stern and Hammond (2004) have carried out a study to determine the relationship between number of purchases and the consumer loyalty, which based on three leading brands and one minor brand laundry detergents.

In this study, a similar trend was observed for all the detergent brands where as the number of purchases increases, the brand loyalty declines exponentially in the first 60 purchases and then stabilizes until it reach the 200 purchases. This study also indicates that the leading brands have higher loyalty levels among consumers as compared to smaller brands.

\subsection{Environmental Regulation}

From the detergent industry perspective, the manufacturers are currently in the stage of shifting their attention towards green and eco-friendly based laundry products. The escalating price of petrochemical based surfactants and the adverse effect of phosphate-builder on aquatic environment are among the reasons for the transformation in the detergent industry (Lafferty, 2010). The volatility of the crude oil prices in the late nineties had resulted in the price hike of synthetic surfactant prices (Foster, 2006; Scheibel, 2004) and as a countermeasure the detergent industry has opted for oleo-based surfactants.

Phosphate-builders, on the other hand, have been regarded as culprits responsible to cause eutrophication of water bodies (Schweiker, 1981; Schwuger \& Liphard, 1989) and many countries have imposed new environmental policies to phase-out these builders from laundry detergent products. Over the last decade, the production of phosphate incorporated detergent products has been very rare in the United States (McCoy, 2000). Recently, the European Parliament also has implemented a new regulation to limit the usage of phosphate builder in all consumers LDP (http://www.euractiv.com/specialweek-waterpolicy/parliament-backs-limitsphosphates-news-509724). Other countries such as Japan, Korea and China are now using zeolite as replacement to phosphates in their laundry detergent products. However, in India and other Asian nations, the phosphates are still being used (Lafferty, 2010). From the viewpoint of consumers, it appears to be that the more involved the consumers are with the environmental issues, the greater will be the tendency for them to purchase green products (Schuhwerk \& Lefkokk-Hagius, 1995; Chan, 1996).

\subsection{Green Consumers}

Green consumers can be regarded as those who make efforts to protect the environment through various means such as recycling, purchasing green products, saving energy, etc. (Paco, Alves, Shiel, \& Filho, 2009). It has been estimated in 2008 that the green consumers had an annual purchasing power of US\$500 billion (Grimmer \& Bingham, 2013). Although a lion share's of research studies have demonstrated that most of the consumers have concerns towards environment (Laroche, Tomiuk, Bergeron, \& Barbaro-Forleo, 2002; Matthes, Wonneberger, \& Schmuck, 2013) but not all of them are willing to pay a premium for environmental benefits (OECD, 2011). However, the outcome of these studies would not be applicable to certain market segments. This is because some market segments value their product attributes more than others. One example of such market segments is laundry detergents.

Currently, additional efforts are being undertaken by the detergent industry to incorporate the green features and environment benefits in the development of new laundry detergent products. These characteristics indirectly have some sort of influence on the public opinion and consumer attitudes. According to the survey conducted by Accenture (2010), the percentages of the consumers' willingness to pay extra for green products in two developing countries in Asia are as follows: China (98\%) and India (84\%). In the recent AOCS 2012 Sustainability Survey study, $84.1 \%$ of the Chinese industry experts believed that the Asian consumers rank the degree of green issues from "quite highly" to "very highly".

Another study also has indicated that among all the green issues, natural ingredient is the most important factor for consumers when considering or purchasing detergent products (Genencor, 2011). All these survey results not only shows the high preferences of the consumers towards green and environment friendly products but also on their willingness to pay more. These results reflect the social caring and responsibilities among the consumers towards the world surrounding them. 


\subsection{Research Framework}

Based on the literature review and the conceptual framework described earlier, a study was sought to understand the consumer preferences (detergent format, brand and origin) and their purchasing behavior (awareness/knowledge and perception) towards laundry detergents in general and particularly on MES detergent powders. Figure 2 shows the research framework used for the study.

\section{Research Methodology}

The pilot survey was conducted for three days (16 to 18 February 2011) at "The Waterfront" shopping complex in Desa Parkcity, Kuala Lumpur, Malaysia. This venue was chosen due to its strategic location in Kuala Lumpur where the residents comprise a diverse community and most of them are from above average household income group. A self-administered closed end questionnaire was developed using quantitative approach for the pilot survey. The questionnaire focused on two areas which include the consumers' preferences and the psychological factors that affect their purchasing behaviour. There are five demographic questions and seven specific questions in the questionnaire. The potential consumers were randomly approached and were asked to fill in the survey questionnaire. Box-packs containing 500 gram of detergent powders incorporated with MES were presented as token of appreciation to those consumers participated in the pilot survey. The questions prepared in the survey questionnaire were structured into three parts (a) consumer demographics, (b) consumer preferences, and (c) consumer awareness/knowledge and perception.

\section{DETERGENTS}
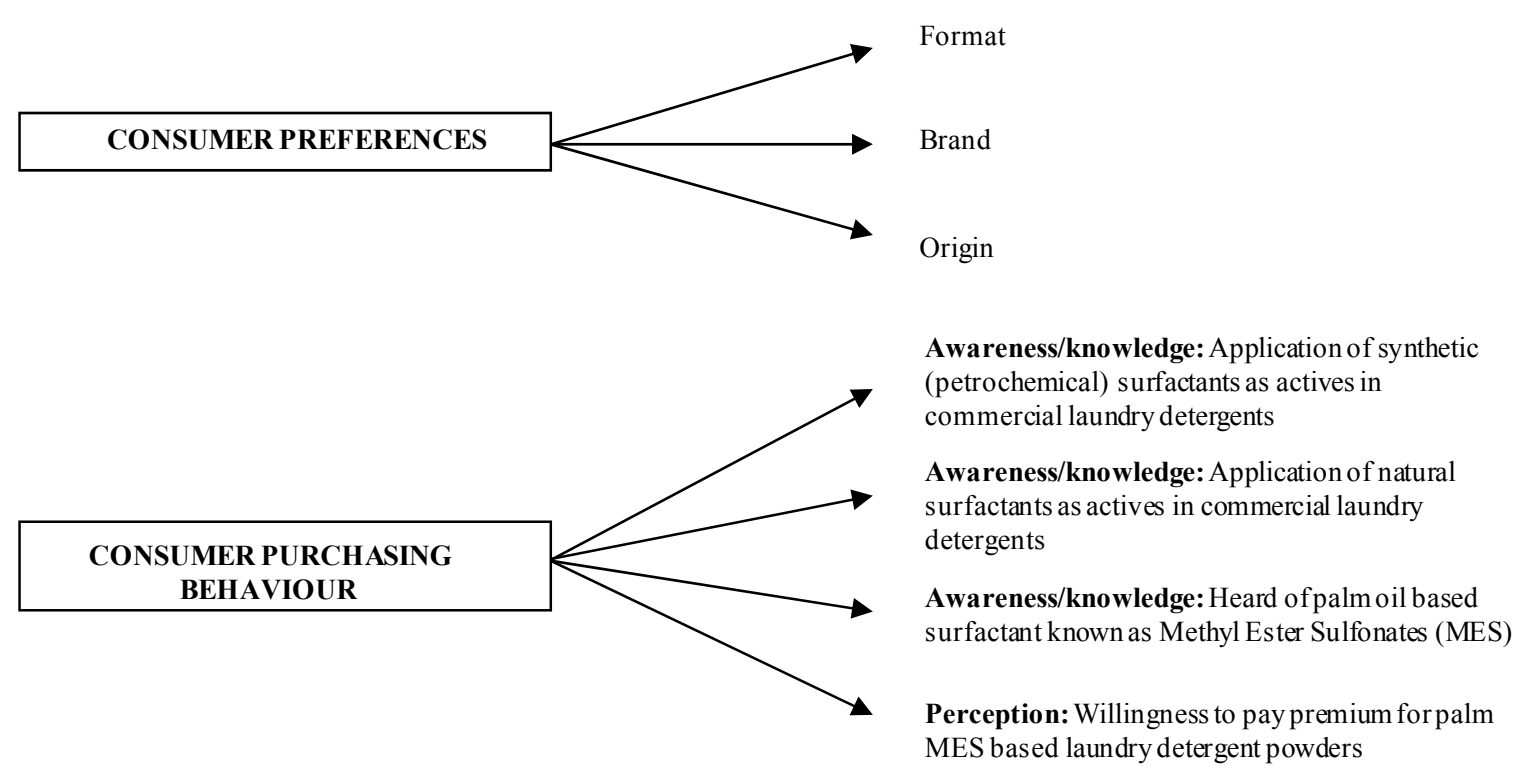

Figure 2. Refined framework of the pilot survey research

Consumers demographics. Five questions were asked to obtain information about respondents' background, which include the following:

- Gender : Male/Female

- Age Group : Below 21/21-30/31-40/Above 40

- Race : Malay/Chinese/Indian/Others

- Education Level : SPM or MCE (equivalent to O Level)/Diploma/Degree/Higher Degree

- Monthly Income : Below RM1,500/RM1,501 - 2,500/RM2,501- 4,000/Above RM4,000

(Note: RM - Ringgit Malaysia)

Consumers preferences towards detergents format, brand and origin. Respondents were requested to answer three questions in accordance to their preferences on the following:

- Please indicate the brand of the laundry detergent you use daily? TOP, FAB, BREEZE, DYNAMO or other brands: 
- Please indicate the type of the laundry detergent used? Liquid/Normal Powder (low-density powder)/ Concentrated Powder (high-density powder)

- Which of these, you would prefer to use, petrochemical or palm oil based laundry detergent? And why (please state your reasons):

TOP and FAB are products of Southern Lion and Colgate Palmolive respectively. BREEZE is a product of Unilever while DYNAMO is produced by Procter \& Gamble.

Consumers awareness/knowledge and perception affecting purchasing behavior. Three questions were asked in relation to consumers' awareness/knowledge on the application of synthetic and natural based actives in laundry detergent products particularly on palm MES detergent. One question was asked to understand consumers' perception by assessing their willingness to pay premium for palm MES based detergent powder. The questions set for the respondents were as follows:

- Are you aware that most laundry detergents are made of synthetic or petrochemical based actives? Yes/No/ Uncertain

- Have you ever used laundry detergent that made of natural based actives? Yes/No

- Have you ever heard about laundry detergent made from palm oil based actives, or known as Methyl Ester Sulfonates (MES)? Yes/No

- Are you willing to pay a premium for the laundry detergent made of palm oil based actives, MES? Yes/No

In the questionnaire, the answer options provided for questions on demographic characteristics and consumers' preferences were straightforward. However, for questions on consumers purchasing behaviour, two different answer rating scales were used. The answer rating scales were prepared according to Guttman scale, which include the binary Yes/No and ternary Yes/Uncertain/No scales. These data, which gathered from the survey questionnaire, were analyzed by computing various descriptive statistics such as means, standard deviations, standard errors, lower 95\% confidence limit and upper 95\% confidence limit. Both lower and upper 95\% confidence limits were calculated in order to express the reliability of the mean. These descriptive statistics were computed to figure out the extent of knowledge/awareness and perception level among consumers towards laundry detergents in general and more specifically on palm MES based laundry detergents.

\section{Results and Discussion}

\subsection{Demographic Characteristics}

A summary of respondents' demographic profile is presented in Table 1. Out of the total respondents participated $(n=112)$ in the survey, $33.9 \%(n=38)$ were females as opposed to $66.1 \%(n=74)$ males. Almost $70 \%$ of the respondents are Chinese while the remaining includes Malay (18.8\%), Indian (3.6\%) and others (8\%). In terms of education level, about $53 \%$ of the respondents have attained tertiary education while others include diploma holders (20.5\%) and high school certificate holders (25.9\%). About $17 \%$ of the total respondents earn a monthly income of less than RM1,500, 35.8\% receive from RM1,501 to RM4,000 while $47.3 \%$ earn above RM4,000. It was also observed that majority of the respondents (74.1\%) are from the age group of above 30 years old and they are generally represents by those who are married and actively involved in household chores.

\subsection{Preferences towards Detergent Brand}

The graphical illustration of the survey results with relation to the detergent brand preferences are shown in Figure 3. Based on Figure 3a, the survey found that TOP was the most preferred brand for laundry detergents. A total of $38.6 \%$ of the overall respondents prefer this particular brand. DYNAMO, which is the close competitor to TOP in Malaysia, was preferred as second choice and it represents $32.7 \%$ of the total respondents. These results are in total agreement with the 2012 home care country report released by Euromonitor International. In this country report, Southern Lion's TOP brand was acknowledged as the leading brand for laundry care in Malaysia (http://www.euromonitor.com/home-care-in-malaysia/report).

Figure $3 b-3 f$ indicates the respective demographics (gender, age group, race, education level and monthly income) on preferred laundry detergent brands. From the total respondents, almost $65 \%$ of male and $75 \%$ of female were found to be in favor of TOP and DYNAMO than any other brands (Figure 3b). Similar results were also obtained for age group of above 30 years old. About $39 \%$ of the respondents from this age group prefer TOP brand while another $36 \%$ are in favor of DYNAMO brand (Figure 3c).

Among the Chinese community, which is the largest race group residing close to the survey location, TOP (51\%) and DYNAMO (32\%) are the most preferred brand for laundry detergents (Figure 3d). Other brands can be 
considered as not popular to this community. TOP also seemed to be well-liked by respondents from all education levels and monthly income groups except for those who in the category of postgraduate degree and have a monthly income of above RM4,000 (Figure 3e and 3f). This category of respondents prefers DYNAMO more than TOP.

Table 1. Demographic profile of respondents

\begin{tabular}{llrr}
\hline \multirow{2}{*}{ Variables } & & \multicolumn{2}{c}{ Sample $(\mathrm{n}=112)$} \\
\cline { 2 - 4 } Gender & Male & Frequency & \% \\
\hline \multirow{3}{*}{ Age Group } & Female & 78 & 33.9 \\
& Below 21 & 5 & 66.1 \\
& $21-30$ & 24 & 4.5 \\
Race & $31-40$ & 42 & 37.5 \\
& Above 40 & 41 & 36.6 \\
& Malay & 21 & 18.8 \\
& Chinese & 78 & 69.6 \\
& Indian & 4 & 3.6 \\
& Others & 9 & 8.0 \\
& High school certificate, SPM or equivalent & 29 & 25.9 \\
& Diploma & 23 & 20.5 \\
& Bachelor's degree & 23 & 20.5 \\
& Postgraduate degree & 19 & 17.0 \\
& Not mentioned & 18 & 16.1 \\
& Below RM1,500 & 19 & 17.0 \\
& RM1,501 - RM2,500 & 20 & 17.9 \\
& RM2,501 - RM4,000 & 20 & 17.9 \\
& Above RM4,000 & 28 & 25.0 \\
& Not mentioned & 25 & 22.3 \\
\hline
\end{tabular}

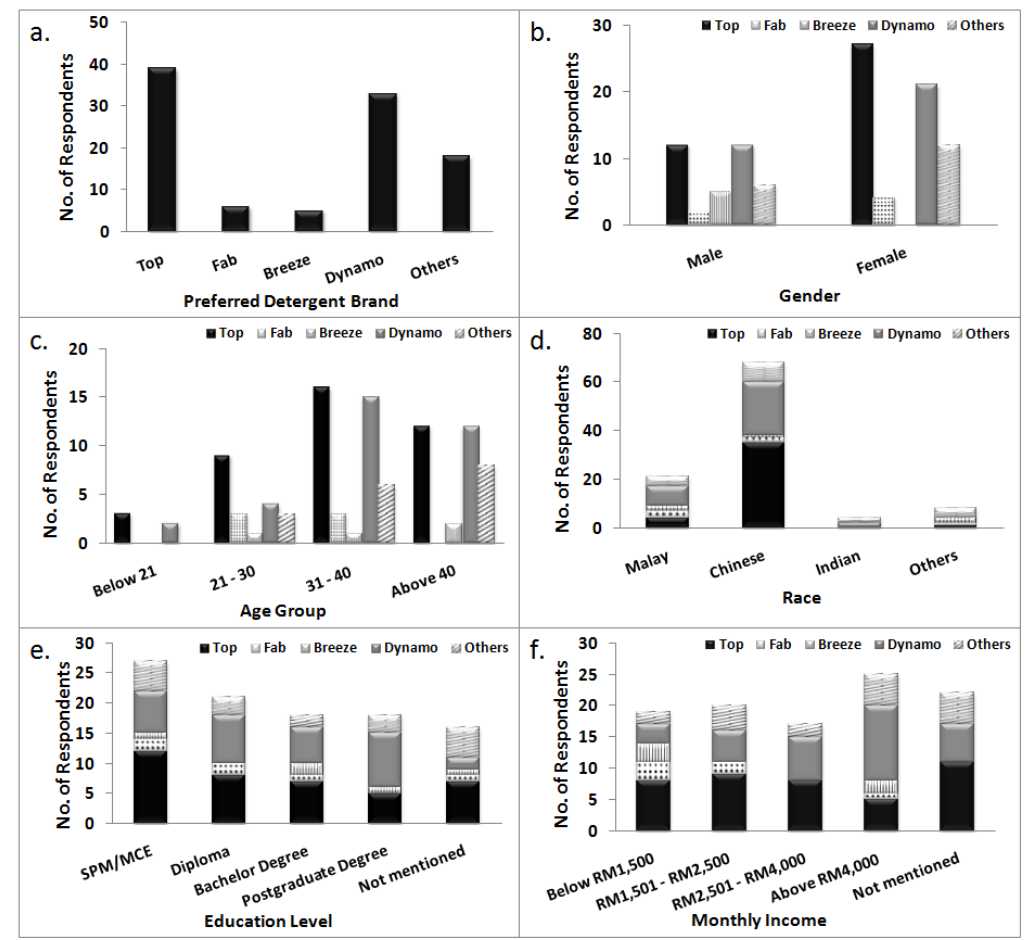

Figure 3. Preferred laundry detergent brand among (a) overall respondents, (b) gender demographics, (c) age demographics, (d) race demographics, (e) educational level demographics, and (f) monthly income demographics 


\subsection{Preferences towards Detergent Format}

The survey results with reference to the detergent format preferences are presented graphically in Figure 4 . According to Figure $4 \mathrm{a}$, the most preferred detergent format among the respondents was liquid detergent (43\%). This was followed sequentially by normal powder (36\%) and concentrated powder (21\%). In Malaysia, particularly the urban areas, the ratio of consumers using liquid detergents over powder detergents is relatively high. However, the consumers in rural areas, on the contrary, have high preferences towards normal detergent powders because the cost of normal powders is significantly lower than the liquid formats.

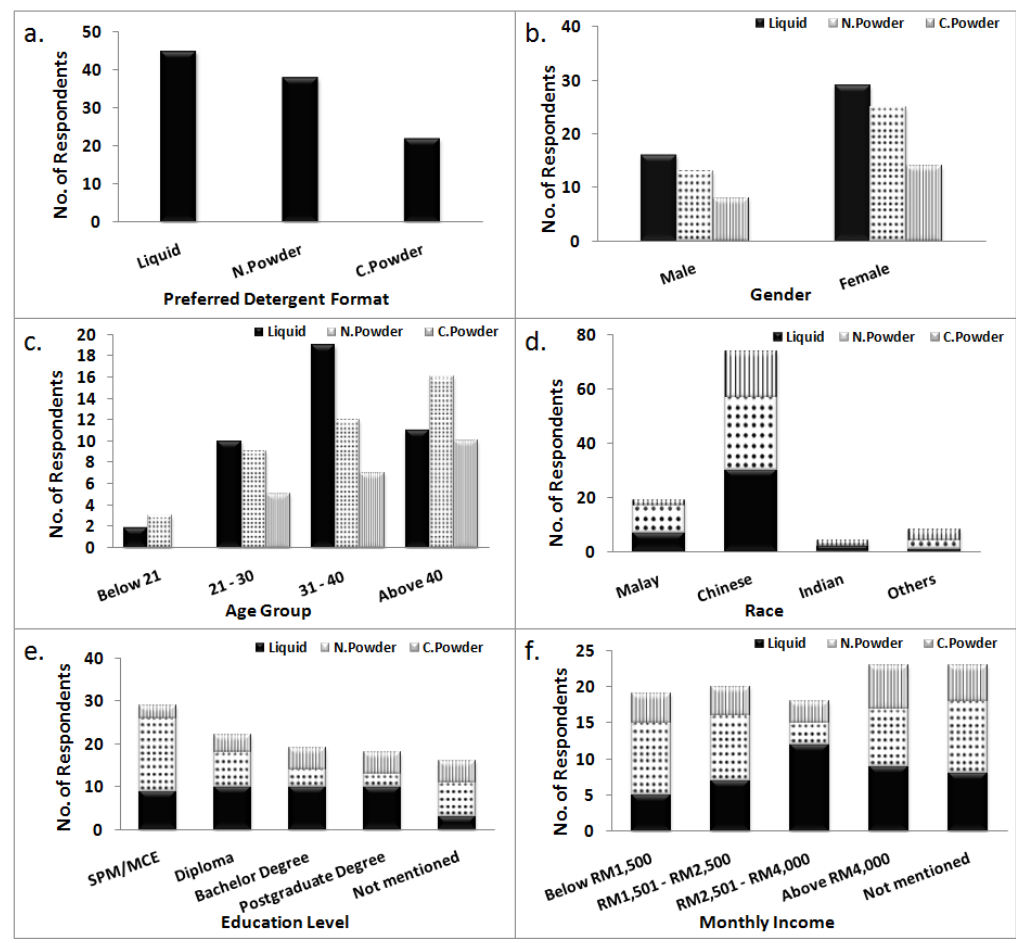

Figure 4. Preferred laundry detergent format among (a) overall respondents, (b) gender demographics, (c) age demographics, (d) race demographics, (e) educational level demographics, and (f) monthly income demographics

Figure $4 \mathrm{~b}-4 \mathrm{f}$ indicates the respective demographics (gender, age group, race, education level and monthly income) on preferred laundry detergent formats. About $43 \%$ of both male and female respondents likewise have indicated that they prefer liquid detergents more than powders (Figure 4b). Meanwhile, the respondents in the category of above 30 years old who normally spend a great deal of time in the household tasks, favors liquid detergents (40\%) more than normal powders (37\%) and concentrated detergent powders (23\%) (Figure 4c).

Among the race group, the Chinese being the majority of the respondents shows high preferences towards liquid detergents $(41 \%)$ while normal detergent powders was favored as the second choice $(36 \%)$. In contrast, the Malays prefer normal powders (53\%) than the liquid detergents (37\%) (Figure 4d). This could be due to economic reasons where the normal powders are offered at lower price as compared to other formats. The data obtained on education level has supported these findings as well where it shows a correlation between the education level of the respondents and their preferences towards detergent formats. The higher the education level, the higher will be their preferences towards liquid detergents (Figure 4e). Similarly, the higher the monthly income of the respondents, the preferences towards liquid detergents will be higher than any other formats (Figure 4f).

\subsection{Preferences towards Detergent Origin}

The preferences towards detergent origin among the overall respondents are plotted graphically in Figure 5. Based on survey results received from $82 \%$ of the total respondents, it was observed that about $94 \%$ of them prefer the palm oil based detergent than the petrochemical based detergent. This overwhelming majority may be due to two possible reasons: a). green features and environmental benefits offered by the palm oil based detergents and b). green awareness among consumers (Figure 5a). 


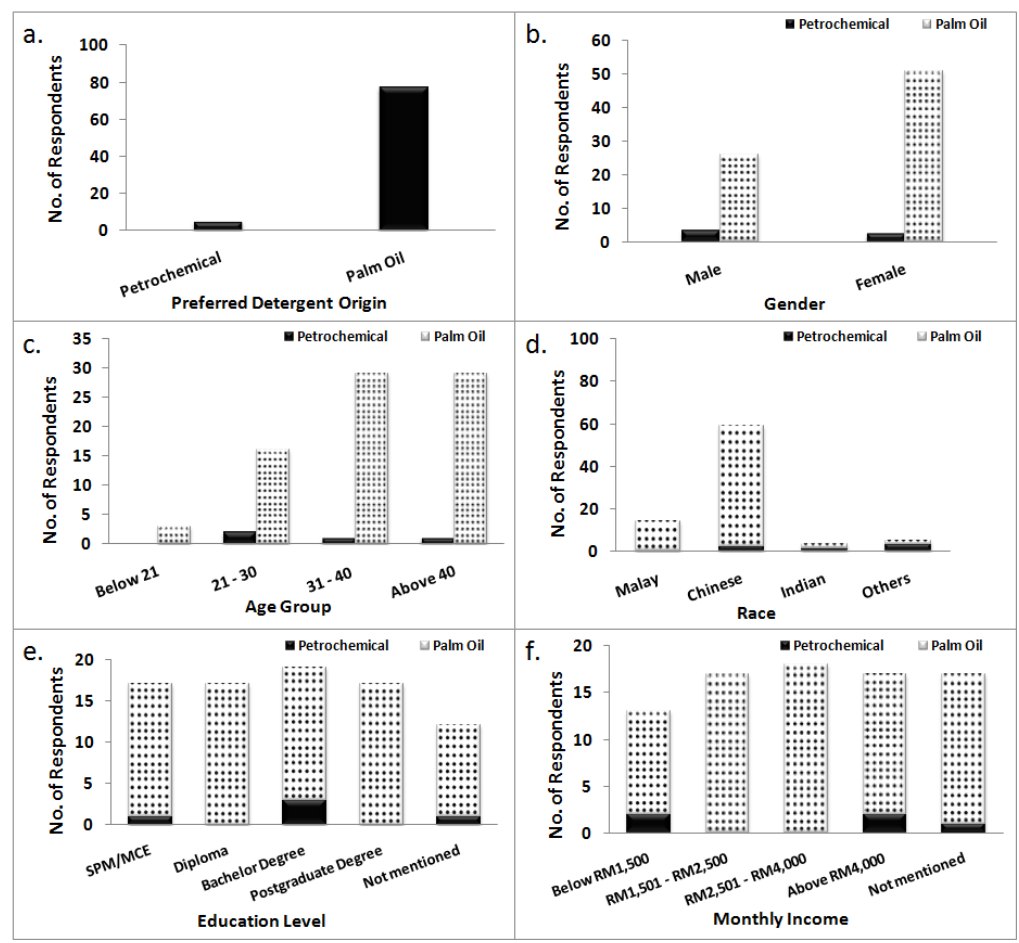

Figure 5. Preferred laundry detergent origin among (a) overall respondents, (b) gender demographics, (c) age demographics, (d) race demographics, (e) educational level demographics, and (f) monthly income demographics

Figure $5 \mathrm{~b}-5 \mathrm{f}$ indicates the respective demographics (gender, age group, race, education level and monthly income) on preferred detergent origin. Approximate $90 \%$ of male and $96 \%$ of female respondents have indicated their strong preferences towards palm oil based detergent over petrochemical based detergent (Figure $5 \mathrm{~b}$ ). The female respondents were found to have greater environmental concern than male respondents. Past studies also reports similar findings in which women were seen to express greater environmental concern than men due to their different value and belief systems over environment issues (Mostafa 2007). Furthermore, the survey results also have demonstrated that the preferences towards palm oil based detergents for all age groups are considerably higher than the petrochemical based detergents (Figure 5c).

The major three races in Malaysia are Malays, Chinese and Indians. These three races were found to completely in favor of the palm oil based detergents than the petrochemical based detergents (Figure 5d). Other than the race group, a similar trend was observed for education level and monthly income groups, where all the groups have indicated high preferences towards palm based detergents than the petrochemical based detergents (Figure 5e and $5 \mathrm{f}$ respectively). Overall, these findings have demonstrated a high degree of affinity among consumers towards products that derived from natural ingredients.

\subsection{Awareness/Knowledge on the Application of Synthetic Surfactants as Laundry Detergent Actives}

Table 2. Respondents statistical scores for awareness/knowledge on application of synthetic/petrochemical surfactants

\begin{tabular}{lcccccc}
\hline $\begin{array}{l}\text { Psychological } \\
\text { Factors }\end{array}$ & $\begin{array}{l}\text { Response } \\
\text { Rate (\%) }\end{array}$ & Mean & $\begin{array}{l}\text { Standard } \\
\text { Deviation }\end{array}$ & $\begin{array}{l}\text { Number of } \\
\text { Respondents }\end{array}$ & $\begin{array}{c}\text { Standard } \\
\text { Errors }\end{array}$ & $\begin{array}{l}\text { Lower 95\% limit, } \\
\text { Upper 95\% limit }\end{array}$ \\
\hline $\begin{array}{l}\text { Awareness/Knowledge: } \\
\begin{array}{l}\text { Application of synthetic } \\
\text { surfactants as actives in } \\
\text { commercial laundry }\end{array}\end{array}$ & & & & & & \\
\begin{tabular}{l} 
laundry detergents* \\
\hline
\end{tabular} & 1.089 & 0.79 & 112 & 0.074 & $0.943,1.235$ \\
\hline
\end{tabular}

Note. *Scale rating: No -0 , Uncertain -1 , Yes -2 
Table 2 shows the respondents' statistical scores, which was calculated using a three point scale. The calculated mean for this respondents' awareness/knowledge is 1.089 while the standard deviation is 0.79 . Based on the respondents' statistical scores, the findings explicitly show that on average the respondents were uncertain on the application of synthetic surfactants as actives in commercial laundry detergents. This situation occurs for two possible reasons. One of them can be due insufficient information on the detergent product label. Another reason is that the detergent manufacturers normally tend to keep the formula and ingredients of their laundry detergent products as trade secrets.

\subsection{Awareness/Knowledge on the Application of Natural Surfactants as Actives in Commercial Laundry Detergents}

The statistical scores for this respondents' awareness/knowledge, which tabluated in Table 3, was calculated using a two point scale. The calculated mean and standard deviation for this awareness are 0.182 and 0.39 respectively. These statistical scores strongly indicate lack of awareness/knowledge among the respondents on application of natural surfactants as actives in commercial laundry detergents. Similarly to synthetic surfactants, these natural surfactants are also lesser known as detergent actives among the respondents.

Table 3. Respondents statistical scores for awareness/knowledge on application of natural surfactants

\begin{tabular}{lcccccc}
\hline $\begin{array}{l}\text { Psychological } \\
\text { Factors }\end{array}$ & $\begin{array}{c}\text { Response } \\
\text { Rate (\%) }\end{array}$ & Mean & $\begin{array}{l}\text { Standard } \\
\text { Deviation }\end{array}$ & $\begin{array}{l}\text { Number of } \\
\text { Respondents }\end{array}$ & $\begin{array}{c}\text { Standard } \\
\text { Errors }\end{array}$ & $\begin{array}{l}\text { Lower 95\% limit, } \\
\text { Upper 95\% limit }\end{array}$ \\
\hline $\begin{array}{l}\text { Awareness/Knowledge: } \\
\begin{array}{l}\text { Application of natural } \\
\text { surfactants as actives in } \\
\text { commercial laundry } \\
\text { laundry detergents* }\end{array}\end{array}$ & 98.2 & 0.182 & 0.39 & 110 & 0.037 & $0.110,0.254$ \\
\hline
\end{tabular}

Note. $*$ Scale rating: $\mathrm{No}-0, \mathrm{Yes}-1$

\subsection{Awareness/Knowledge on the Existence of Palm Based Surfactant, MES}

Previous findings have indicated low level of awareness/knowledge among respondents on application of natural surfactants in laundry detergents. Likewise, a similar low level of awareness/knowledge was observed for palm based MES, which can be seen in Table 4. The calculated mean and standard deviation for this respondents' awareness, which calculated using a two point scale, are 0.189 and 0.39 respectively.

\subsection{Perception on Willingness to Pay Premium for Palm MES Detergent Powder}

Table 5 indicates the statistical scores for respondents' perception, which calculated using a two point scale. The calculated mean for this perception is 0.831 while the standard deviation is 0.37 . The respondents' statistical scores indicate that the willingness among respondents to pay a premium for palm MES detergent powder is reasonably high. Most of the respondents were found to have some level of understanding about the benefits of eco-friendly products and this could be the reason for the high statistical scores. In addition, higher education level among the respondents was seen as another important factor, which affects the consumer willingness in paying the premium.

Table 4. Respondents statistical scores for awareness/knowledge on existence of palm based MES

\begin{tabular}{lllllll}
\hline $\begin{array}{l}\text { Psychological } \\
\text { Factors }\end{array}$ & $\begin{array}{l}\text { Response } \\
\text { Rate (\%) }\end{array}$ & Mean & $\begin{array}{l}\text { Standard } \\
\text { Deviation }\end{array}$ & $\begin{array}{l}\text { Number of } \\
\text { Respondents }\end{array}$ & $\begin{array}{c}\text { Standard } \\
\text { Errors }\end{array}$ & $\begin{array}{c}\text { Lower 95\% limit, } \\
\text { Upper 95\% limit }\end{array}$ \\
\hline
\end{tabular}

Awareness/Knowledge:

Heard of palm based

surfactant - Methyl

94.6

0.189

0.39

106

0.038

$0.115,0.263$

Ester Sulfonates

(MES)*

Note. ${ }^{*}$ Scale rating: No -0, Yes -1 
Table 5. Respondents statistical scores on willingness to pay a premium for palm MES detergent powder

\begin{tabular}{lcccccc}
\hline $\begin{array}{l}\text { Psychological } \\
\text { Factors }\end{array}$ & $\begin{array}{l}\text { Response } \\
\text { Rate (\%) }\end{array}$ & Mean & $\begin{array}{l}\text { Standard } \\
\text { Deviation }\end{array}$ & $\begin{array}{l}\text { Number of } \\
\text { Respondents }\end{array}$ & $\begin{array}{l}\text { Standard } \\
\text { Errors }\end{array}$ & $\begin{array}{l}\text { Lower 95\% limit, } \\
\text { Upper 95\% limit }\end{array}$ \\
\hline $\begin{array}{l}\text { Perception: } \\
\begin{array}{l}\text { Willingness to pay } \\
\text { premium for palm }\end{array}\end{array}$ & 79.5 & 0.831 & 0.374 & 89 & 0.040 & $0.753,0.909$ \\
$\begin{array}{l}\text { MES based laundry } \\
\text { detergent powder* }\end{array}$ & & & & & & \\
\hline
\end{tabular}

Note. $*$ Scale rating: No -0, Yes -1

\section{Conclusion}

Since the beginning of the new millennium, the term "green and eco-friendly" has been regarded globally as the way forward for production and marketing of laundry detergents. With respect to this development, high performance non-phosphate MES detergent powders, which formulated using binary surfactants of palm oil based C16MES and linear alkyl benzene sulfonic acid (LABSA), were developed. In this paper, a pilot survey was carried out to study consumers' preferences and their purchasing behaviour for both commercial laundry detergent products and MES detergent powders. The pilot survey results have showed that the majority of survey respondents were neither have the knowledge about MES detergent powder nor heard of its surfactants but their preferences to use this new eco-friendly product were generally positive. Most of the consumers were found to have intellectual orientation to value the environment. Due to their strong commitment towards greener lifestyles, respondents are also willing to pay a premium for MES detergent powder. However, there is limitation in this study where the pilot survey was carried out in one particular location and in order to corroborate the pilot survey findings, a more comprehensive survey covering several more locations is required.

\section{Acknowledgements}

The authors are grateful to the Ministry of Science, Technology and Innovation (MOSTI) of Malaysia (Project reference: TF0208D024) and Ministry of Education (MOE) of Malaysia for the cooperation and financial support of this project.

\section{References}

Accenture (2010). Accenture consumer electronics products and services usage report. Retrieved from http:// www.accenture.com/SiteCollectionDocuments/PDF/Accenture_India_Online_PDF_20310_FINAL.pdf

Adami, I. (2008). The challenge of the anionic surfactant industry. INFORM: A Special Supplement Biorenewable Resources, 5(19), 10-11.

Ahmad, S., Kang, Y. B., \& Yusuf, M. (2000). Basic oleochemicals. In Y. Basiron, B. S. Jalani, \& K. W. Chan (Eds.), Advances in oil palm research. Bandar Baru Bangi, Malaysia: Malaysian Palm Oil Board.

Boerefijn, R., Dontula, P., \& Kohlus, R. (2007). Detergent granulation. In A. D. Salman, M. J. Hounslow, \& J. P. K. Sevilled (Eds.), Handbook of powder technology (Vol. 11, pp. 673-703). Amsterdam: Elsevier.

Bhagat, K. J. (2012). Consumer behaviour of teenage with reference to fast moving consumer goods (FMCG) in the Mumbai region - Maharashtra, India. Proceedings of the International Conference on Business Management \& Information Systems. Singapore: Singapore Management University.

Chan, T. (1996). Concerns for environmental issues and consumer purchase preferences: a two-country study. Journal of International Consumer Marketing, 9, 43-55. http://dx.doi.org/10.1300/J046v09n01_04

Chemsystems. (2007). Linear alkyl benzene (LAB). Retrieved from http://www.chemsystems.com/about/cs/news/ items/PERP\%200708S7_LAB.cfm

China Cleaning Industry Association. (2011). The market analysis of laundry detergent powder and additives. Green Chemical 3. Retrieved from http://www.greenchemical.jp/ member/201110/eng/tokushu3.pdf

Choudhury, S., \& Kakati, R. P. (2013). Measuring customer based brand equity for premium detergent brands in the Indian market. Pacific Business Review International, 6, 1-10.

De Guzman, D. (2010). Guangzhou surfactant plant in China to start up in Q2 2011. Retrieved from http://www. icis.com/Articles/2010/10/07/9399640/guangzhou-surfactant-plant-in-china-to-start-up-in-q2-2011.html 
Domzal, T., \& Unger, L. (1997). Emerging positioning strategies in global marketing. Journal of Consumer Marketing, 4, 23-40. http://dx.doi.org/10.1108/eb008208

DuPont (2012). AOCS 2012 sustainability survey results - a different angle (part 4). Retrieved from http://biosciences.dupont.com/fileadmin/user_upload/genencor/documents/15501480_DuPont_AOCS_Surv ey_Results.pdf

Edser, C. (2010). Surfactant manufacturers look for green but cheap petro-alternatives. Focus on Surfactants, 12, 3.

Edser, C. (2011). KLK invests ringgit 706M in plants, R\&D centre. Focus on Surfactants, 11, 3.

Edser, C. (2013). New sulfonation plant for KLK. Focus on Surfactants, 4, 3.

Eurativ.com. (2011). Parliament backs limit on phosphates. Retrieved from http://www.euractiv.com/special week-waterpolicy/parliament-backs-limits-phosphates-news-509724

Euromonitor International. (2011). Ingredients trends in powder detergents-a bright clean future. Retrieved from http://euromonitor.typepad.com/files/ingredients-trends-in-powder-detergents-a-bright-clean-future.pdf

Euromonitor International. (2012). Home care in Malaysia. Retrieved from http://www.euromonitor.com/home -care-in-malaysia/report

Euromonitor International. (2013). 2013 Indian consumer laundry study. Retrieved from http://fhc.biosciences. dupont.com/file admin/userupload/live/fhc/DuPont-Indian-Laundry-Study-infographic.pdf

Foster, N. (2006). Gimme a break! (price, that is). Methyl ester sulfonates. INFORM: A Special Supplement Biorenewable Resources, 3(17), 3.

Genencor (2011). AOSDAC 2011 sustainability survey results: a different angle (part 3). Retrieved from http://www.genencor.com/fileadmin/user_upload/genencor/documents/Genencor_AOSDAC_SurveyResults _A4_030212.pdf

Giese, T. (2006). Methyl ester sulfonate industry poll. Methyl ester sulfonates. INFORM: A Special Supplement Biorenewable Resources, 3(17), 4-6.

Grimmer, M., \& Bingham, T. (2013). Company environmental performance and consumer purchase intentions. Journal of Business Research, 66, 1945-1953. http://dx.doi.org/10.1016/j.jbusres.2013.02.017

Guala, F., \& Merlo, E. (2013). An eco-friendly surfactant for laundry detergents. Surfactants, Household and Personal Care Today, 8, 19-21.

Huber, L. (1989). Conclusions for an ecological evaluation of LAS. Tenside Surfactants Detergents, 26, 71-74.

India News Network Digest. (1994). Multinational succeed with innovative pricing strategies in India. India News Network Digest, 2, 305.

Kent, J. A. (2012). Handbook of industrial chemistry and biotechnology. New York, NY: Spring Science + Business Media.

Kohler J. (2006). Detergent phosphates - an EU policy assessment. Journal of Business Chemistry, 3, 15-30.

Kulkarni, P. M. (2011). Study of rural consumer behavior in relation with washing powder. International Journal of Research in Commerce and Management, 2, 108-110.

Laroche, M., Tomiuk, M., Bergeron, J., \& Barbaro-Forleo, G. (2002). Cultural differences in environmental knowledge, attitudes, and behaviors of Canadian consumers. Canadian Journal of Administrative Sciences, 19, 267-283. http://dx.doi.org/10.1111/j.1936-4490.2002.tb00272.x

Lafferty, M. (2010). Detergent chemistry has hit the wall on clean, so it's going green. INFORM, 21, 465-528.

Malaysian Department of Statistics. (2014). Population and vital statistics: 2013. Retrieved from http://www. statistics.gov.my/portal/download_Buletin_Bulanan/files/BPBM/2014/JAN/MALAYSIA/02Population.pdf

Matthes, J., Wonneberger, A., \& Schmuck, D. (2013). Consumers green involvement and the persuasive effects of emotional versus functional ads. Journal of Business Research, 67, 1885-1893. http://dx.doi.org/10.1016 /j.jbusres.2013.11.054

McCoy, M. (2000). Soap and detergents: if a box or bottle of laundry detergent says new or improved on the label, chances are that a chemical company had a role bringing it to market. Chemical and Engineering News, 78, 37-52. http://dx.doi.org/10.1021/cen-v078n040.p037 
Mohankumar, T. P., \& Shivaraj, B. (2010). Product mix strategies: FMCG in Indian market. SCMS Journal of Indian Management, April-June, 39-54.

Mostafa, M. M. (2007). Gender differences in Egyptian consumers green purchase behaviour: the effects of environmental knowledge, concern and attitude. International Journal of Consumer Studies, 31, 220-229. http://dx.doi.org/10.1111/j.1470-6431.2006.00523.x

OECD. (2011). OECD studies on environmental policy and household behaviour greening household behaviour the role of public policy. http://dx.doi.org/10.1787/9789264096875-en

Okbah, M. A., Ibrahim, A. M. A., \& Gamal, M. N. M. (2013). Environmental monitoring of linear alkyl benzene sulfonates and physicochemical characteristics of seawater in El-Mex Bay (Alexandria, Egypt). Environmental Monitoring and Assessment, 185, 3103-3115. http://dx.doi.org/10.1007/s10661-012-2776-9

Paço, A., Alves, H., Shiel, C., \& Filho, W. L. (2009). Development of a green consumer behaviour model. International Journal of Consumer Studies, 37, 414-421. http://dx.doi.org/10.1111/ijcs.12009

Reznik, G. O., Vishwanath, P., Pynn, M. A., Sitnik, J. M., Todd, J. J., Wu, J., J., Jiang, Y., Keenan, B. G., Castle, A. B., Haskell, R. F., Smith, T. F., Somasundaran, P., \& Jarrell, K. A. (2010). Use of sustainable chemistry to produce an acyl amino acid surfactant. Applied Microbiology and Biotechnology, 85, 1387-1397. http://dx.doi.org/10.1007/s00253-009-2431-8

Samadi, M. (2003). Consumer behavior (1st ed.). Tehran, Iran: Aieizh Publications.

Scheibel, J. J. (2004). The evolution of anionic surfactant technology to meet the requirements of the laundry detergent industry. Journal of Surfactants and Detergents, 7, 319-328. http://dx.doi.org/10.1007/s11743004-0317-7

Schiffman, L. G., \& Kanuk, L. L. (1987). Consumer behavior (3rd ed.). New Jersey, NJ: Prentice-Hall.

Schilling, M. (2005). Strategic management of technological innovation. New York, NY: McGraw-Hill/Irwin.

Schuhwerk, M., \& Lefkokk-Hagius, R. (1995). Green or not-green? Does type of appeal matter when advertising a green product? Journal of Advertising, 24, 45-55. http://dx.doi.org/10.1080/00913367.1995.10673475

Schweiker, G. C. (1981). Detergent builders. Journal of American Oil Chemists Society, 58, 170A-173A. http://dx.doi.org/10.1007/BF02672225

Schwuger, M. J., \& Liphard, M. (1989). Sodium-aluminium-silicates in the washing process - part X: cobuilder and optical brighteners. Colloid and Polymer Science, 267, 336-344. http://dx.doi.org/10.1007/BF01413627

Shepsle, K. A., \& Bonchek, M. S. (1997). Analyzing politics: rationality, behaviours and institutions, New York, NY: W. W. Norton \& Company.

Siwayanan, P. (2005, June 27). A clean sweep. New Straits Times (p. 19).

Siwayanan, P., Aziz, R., Abu Bakar, N., Ya, H., Jokiman, R., \& Chelliapan, S. (2014a). Detergency stability and particle characterization of phosphate-free spray dried detergent powders incorporated with palm C16 methyl ester sulfonate (C16MES). Journal of Oleo Science, 63(6), 585-592. http://dx.doi.org/10.5650 /jos.ess 13200

Siwayanan, P., Aziz, R., Abu Bakar, N., Ya, H., Jokiman, R., \& Chelliapan, S. (2014b). Characterization of phosphate-free detergent powders incorporated with palm C16 methyl ester sulfonate (C16MES) and linear alkyl benzene sulfonic acid (LABSA). Journal of Surfactants and Detergents, 17(5), 871-880. http://dx.doi. org/10.1007/s11743-014-1603-4

Stern, P., \& Hammond, K. (2004). The relationship between customer loyalty and purchase incidence. Marketing Letters, 15, 5-19. http://dx.doi.org/10.1023/B:MARK.0000021967.80283.c8

Yazaki, M., Tanaka, H., \& Nakamura, M. (1984). U.S. Patent No. 4,478,735. Retrieved from http://www. uspto.gov

\section{Copyrights}

Copyright for this article is retained by the author(s), with first publication rights granted to the journal.

This is an open-access article distributed under the terms and conditions of the Creative Commons Attribution license (http://creativecommons.org/licenses/by/3.0/). 